\title{
PHYTODIVERSITY AND ECOLOGICAL FEATURES OF WEED SPECIES OF SUFAID SUNG, PESHAWAR
}

\author{
Abdullah', Syed Mukarram Shah ${ }^{2}$, Adnan Ali Shah ${ }^{1}$, Murad Muhammad ${ }^{1}$, \\ Muhammad Abdussalam ${ }^{1}$, Khushnood Ur Rehman ${ }^{3}$ and Haroon Khan ${ }^{4}{ }^{4}$
}

DOI: https://doi.org/10.28941/pjwsr.v27i2.950

\begin{abstract}
Field surveys were carried out to assess the phytodiversity, phenology, leaf size, leaf shape and life form of weed flora of village Sufaid Sung, Peshawar from March 2018 to June 2020. Overall, 95 plant species associated with 31 families have been recorded. Among them Poaceae (22 species), Asteraceae (10 species) followed by Amaranthaceae and Papilionaceae (6 species each), Brassicaceae and Polygonaceae (5 species each), Euphorbiaceae and Solanaceae (4 species each), Chenopodiaceae and Convolvulaceae (3 species each), Apiaceae, Caryophyllaceae, Cyperaceae, Malvaceae and Verbenaceae (2 species each) were the dominant plant families, while the rest of 16 families contributed a single species each. The dominant life form was therophytes (76 species) followed by hemicryptophytes (11 species) and geophytes ( 8 species). Leaf size of the flora showed that the most dominant leaf size class was mesophyll (38 species) followed by macrophyll and microphyll (18 species each), nanopohyll (15 species), leptophyll (5 species) and a single aphyllous species. Sixty eight species had simple leaves while 26 species had dissected leaves. The findings of the study reflects a detailed phytodiversity and ecological features of the weeds that may be important as reference work for the future ecological, weed management and conservational studies.
\end{abstract}

Keywords: Phytodiversity, ethnobotany, ecological features, weeds flora, Peshawar

Citation: Abdullah, S.M. Shah, A.A. Shah, M.Muhammad, M. Abdussalam, K.U. Rehman and H.Khan. 2021. Phytodiversity And Ecological Features Of Weed Species Of Sufaid Sung, Peshawar. Pak. J. Weed Sci. Res., 27 (2):181-190.

${ }^{1}$ Department of Botany, University of Peshawar, Pakistan

${ }^{2}$ Centre of Plant Biodiversity, University of Peshawar, Pakistan

${ }^{3}$ Department of Botany, Islamia College Peshawar, Pakistan

${ }^{4}$ Department of Weeds Science \& Botany, The University of Agriculture Peshawar, Pakistan

*Corresponding author's email: haroonkhan@aup.edu.pk 


\section{INTRODUCTION}

Peshawar, the provincial capital of Khyber Pakhtunkhwa (KP), is located at $34^{\circ} 01^{\prime} \mathrm{N}$ Latitude and $71^{\circ} 35^{\prime} \mathrm{E}$ Longitude with an average elevation of $1086 \mathrm{ft}$. (Khan et al., 2019). Peshawar is situated in a sub-tropical zone with an average temperature range of $40{ }^{\circ} \mathrm{C}$ to 4 ${ }^{\circ} \mathrm{C}$. Winter in Peshawar starts from midNovember to the end of March, followed by a short spring season till end of April. The summer months are May to September. The relative humidity varies from $46 \%$ in June to $76-85 \%$ in August. The yearly average rainfall is $403.9 \mathrm{~mm}$. The highest precipitation is recorded in September having $114.6 \mathrm{~mm}$ which falls to $50 \mathrm{~mm}$ in June (Basit et al., 2019, Khan et al., 2013a).The district area is plain and fertile (Khan and Ali, 2019). Fine alluvium deposits are present in the middle regions of the district. Rich and perforated soil with a quite uniform combination of clay and sand make the region suitable for cultivation. It is blessed with fertile soil and considerable plant biodiversity because of the River Kabul (Usman et al., 2017). The major crops grown are wheat, sugarcane and maize along with the cultivation of different vegetables (Shah et al., 2006, Khan et al., 2011).

Sufaid Sung is the well-known village of District Peshawar located between latitude $34^{\circ} 5.14^{\prime}$ and longitude $71^{\circ} 27.33^{\prime}$ near Warsak Dam on the bank of River Kabul, bordered by Khyber agency, and is about $17 \mathrm{~km}$ away from the main city of Peshawar. Residents of the area are mostly engaged in agriculture and their livelihood is mostly farming.

Pronounced weeds diversity may have a positive impact on the functioning of agro-ecosystems. In current decades, weeds biodiversity in agricultural system has reduced mainly due to advancement of farming practices e.g. weeds control by highly effective herbicides. The weeds grow in the ordinary environment which is part of the vibrant ecosystem and compete with the crops for nutrients, space and light (Iqbal et al., 2017, Khan et al., 2017). Weeds are the main factor to reduce crop yield and is accountable for $18 \%$ grain losses in wheat and $10-60 \%$ losses in maize crop (Gurmani et al., 2020). Due to competition and race for natural resources and faster growth, the weeds are generally considered problematic (Saeed et al., 2020). Several weeds release allelopathic chemicals which can harm the growth and development of crops. Due to their abundant growth in different environmental conditions, the weeds are great competitors to cereal crops (Khan et al., 2017, Naveed et al., 2019). However, these yield losses largely depend on the type of weed flora, abundance, abiotic factors, and their ecological interactions. The floristic composition of weeds may vary with location and their environmental factors (Ibrahim et al., 2019, Uddin et al., 2018).

Therefore, the present study was aimed to enlist the weed flora and their major ecological features. Although different ecological studies have been carried out on weed flora by several researchers, the current study provides the first-ever report on weeds growing in the cultivated and uncultivated area of Sufaid Sung, Peshawar which will provide key information for proper identification and proper management.

\section{MATERIAL AND METHODS}

Field surveys were conducted to record the floristic composition, phenology, leaf size, leaf shape and life forms of weeds of Sufaid Sung, Peshawar, Khyber Pakhtunkhwa at regular intervals of different seasons from March 2018 to December 2020. This study was performed to explore and document the important weed species and wild relatives of the cash crops grown in the area. The research area was thoroughly visited in different seasons for the collection of their weed's flora. The equipment for research work was the map of the area, notebook, pencil, plant presser, old newspaper, polythene bags, knife, compass and digital camera. Three to five specimens were 
collected for each plant species, sequentially marked and appropriately pressed. The old newspapers, blotters, and corrugated sheets were used for drying and pressing. Newspapers were regularly changed after everyday till the complete dryness of the collected plants. The collected plant species were identified with the help of taxonomists, available literature and the flora of Pakistan. Plants were categorized into their life forms and leaf size classes according to (Hussain, 1989). Leaf shapes and phenology were identified during collection in the fields. Identified plant specimens were submitted to the Herbarium, Department of Botany, University of Peshawar, Pakistan.

\section{RESULTS AND DISCUSSION}

\section{Floristic list}

A total of 95 weed species belonging to 31 families and 82 genera were collected from the research area. Out of 31 families, 27 were Dicotyledonous having 60 genera and 69 species $(72.63 \%)$ and 2 families are monocotyledonous with 22 genera and 24species (25.26\%).Two species belonging to two families were Pteridophytes. The dominating family was Poaceae with 22 species (23.19\%) leg behind by Asteraceae with 10 species $(10.5 \%)$ which in turn followed by Amaranthaceae and Papilionaceae with 6 species $(6.3 \%)$ each while Brassicaceae and Polygonaceae contributed 5 species $(5.3 \%)$. Euphorbiaceae and Solanaceae contributed 4 species $(4.2 \%)$ each. Chenopodiaceae and Convolvulaceae contributed 3 species (3.2\%) each. Apiaceae, Caryophyllaceae, Cyperaceae, Malvaceae, and Verbenaceae added 2 species $(2.1 \%)$ while the rest of 16 families contributed 1 species $(1.05 \%)$ each (Table-1,3,4). Similar results have been shown by Ali et al. (2015), Anwar et al. (2020), Hussain et al. (2015), Khan et al. (2013b).Anwar et al. (2020) reported that Poaceae, Asteraceae, and Amaranthaceae as the dominant families in weeds of maize crop in Swabi. Zeb et al. (2017) also reported Poaceae and Asteraceae as the dominant families.

\section{Life form}

The therophytes with 76 species $(80 \%)$ were the dominant life form followed by hemicryptophytes containing 11 species $(11.59 \%)$ which in turn followed by geophytes having 8 species $(8.42 \%)$ (Table-2). Inayat et al. (2014) reported therophytes followed by hemicryptophytes from District Charsadda, Pakistan which agree with our present findings. Naila et al. (2017) also reported the highest diversity of therophytic weeds in garlic crop grown in Botanical Garden, University of Peshawar while Badshah et al. (2016) reported therophytes as an abundant life form in spring and summer plants of Parachinar, Kurram Agency. Hemicryprophytes and phanerophytes show the dominancy at high altitude (Hussain and Ishtiaq, 2009)

\section{Leaf classes}

With the help of Raunkiar's diagram, the leaf classes were analyzed. There are 6 types of leaf classes. The first one (leptophyli) is the smallest in size (25 sq. $\mathrm{mm}$ ) and each class preceded to the next class is larger than the earlier class nine times. From the flora, the leaf size showed that mesophyll was the most dominant leaf size class which contain 38 species (40\%) followed by macrophyll and microphyll with 18 species (18.95\%) each. Nanopohyll represented 15 species (15.79\%) and Leptophyll contributed by 5 species $(5.26 \%)$ while one species was aphyllous. Simple leaf species were 68 (72.34\%) while 26 species $(27.66 \%)$ were with dissected leaves (Table-2).

\section{Phenology}

Phenological stages were recorded as pre-reproductive 12 species (12.63\%), reproductive 69 species $(72.63 \%)$, and post-reproductive 14 species $(14.74 \%)$ as shown in Table-2. In exploring the flora of an area life form and leaf size spectra play a key role during studies. The study of life form and leaf size is an essential kind of 
vegetation description (Khan et al., 2013). The climatic and human disturbance of a particular area can be investigated and showed by Life form and leaf size spectra (Haq et al., 2019).

Table 1. Phytodiversity and ecological features of weed species of Sufaid Sung, Peshawar

\begin{tabular}{llllll}
\hline S.N & $\begin{array}{l}\text { Plant species and botanical } \\
\text { o }\end{array}$ & $\begin{array}{l}\text { Life } \\
\text { forms }\end{array}$ & $\begin{array}{l}\text { Leaf } \\
\text { sizes }\end{array}$ & $\begin{array}{l}\text { Leaf } \\
\text { shapes }\end{array}$ & $\begin{array}{l}\text { Phenol } \\
\text { ogy }\end{array}$ \\
\hline A. & Pteridophytes & & & & \\
\hline
\end{tabular}

1. Equisetaceae

\begin{tabular}{rlrlrl}
\hline 1. & Equisetum arvense L. & G & Ap & Ap & S3 \\
\hline 2. & Pteridaceae & & & & \\
\hline 2. & Pteris vittata L. & G & Mes & Dis & S1 \\
\hline
\end{tabular}

\section{B. Angiosperms}

\section{a. Monocots}

\begin{tabular}{|c|c|c|c|c|}
\hline \multicolumn{5}{|c|}{ Cyperaceae } \\
\hline 3. Cyperus rotundus L. & G & Mic & S & S2 \\
\hline 4. Fimbristylis dichotoma (L.)Vahl & G & Mes & S & S3 \\
\hline \multicolumn{5}{|c|}{ Poaceae } \\
\hline 5. Avena fatua $\mathrm{L}$. & Th & Mes & $\mathrm{S}$ & S2 \\
\hline 6. Bromus catharticus Vahl & Th & Mes & $\mathrm{S}$ & S2 \\
\hline 7. Bromus gracillimus Bunge & Th & Mes & $\mathrm{S}$ & S3 \\
\hline 8. Cynodon dactylon (L.) Pers. & $\mathrm{H}$ & Mic & $\mathrm{S}$ & S2 \\
\hline 9. Cenchrus ciliaris L. & $\mathrm{H}$ & Mes & $\mathrm{S}$ & S2 \\
\hline $\begin{array}{l}\text { 10. Dactyloctenium aegyptium (L.) } \\
\text { Richt. }\end{array}$ & Th & Mic & $\mathrm{S}$ & S2 \\
\hline 11. Desmostachya bipinnata (L.) Stapf & $\mathrm{H}$ & Mes & $\mathrm{S}$ & S2 \\
\hline $\begin{array}{l}\text { 12. Dichanthium annulatum (Forssk.) } \\
\text { Stapf }\end{array}$ & $\mathrm{H}$ & Mes & $\mathrm{S}$ & S2 \\
\hline 13. Digitaria ciliaris (Retz.)Koeler & Th & Mic & $\mathrm{S}$ & S2 \\
\hline 14. Eleusine indica (L.) Gaertn. & $\mathrm{H}$ & Mes & $\mathrm{S}$ & S2 \\
\hline 15. Eragrostis minor Host & Th & Mic & S & S2 \\
\hline 16. Hordeum murinum L. & Th & Mes & $\mathrm{S}$ & S1 \\
\hline 17. Imperata cylindrica (L.)P.Beauv. & $\mathrm{H}$ & Mes & $\mathrm{S}$ & S2 \\
\hline 18. Paspalum distichum L. & $\mathrm{H}$ & Mes & S & S2 \\
\hline 19. Phragmites karka Hook. F. & G & Mac & S & S3 \\
\hline 20. Phalaris minor Retz. & Th & Mes & S & S2 \\
\hline 21. Poa annua L. & Th & Mic & $\mathrm{S}$ & S2 \\
\hline 22. Polypogon monspeliensis (L.) Desf. & Th & Mes & $\mathrm{S}$ & S2 \\
\hline
\end{tabular}




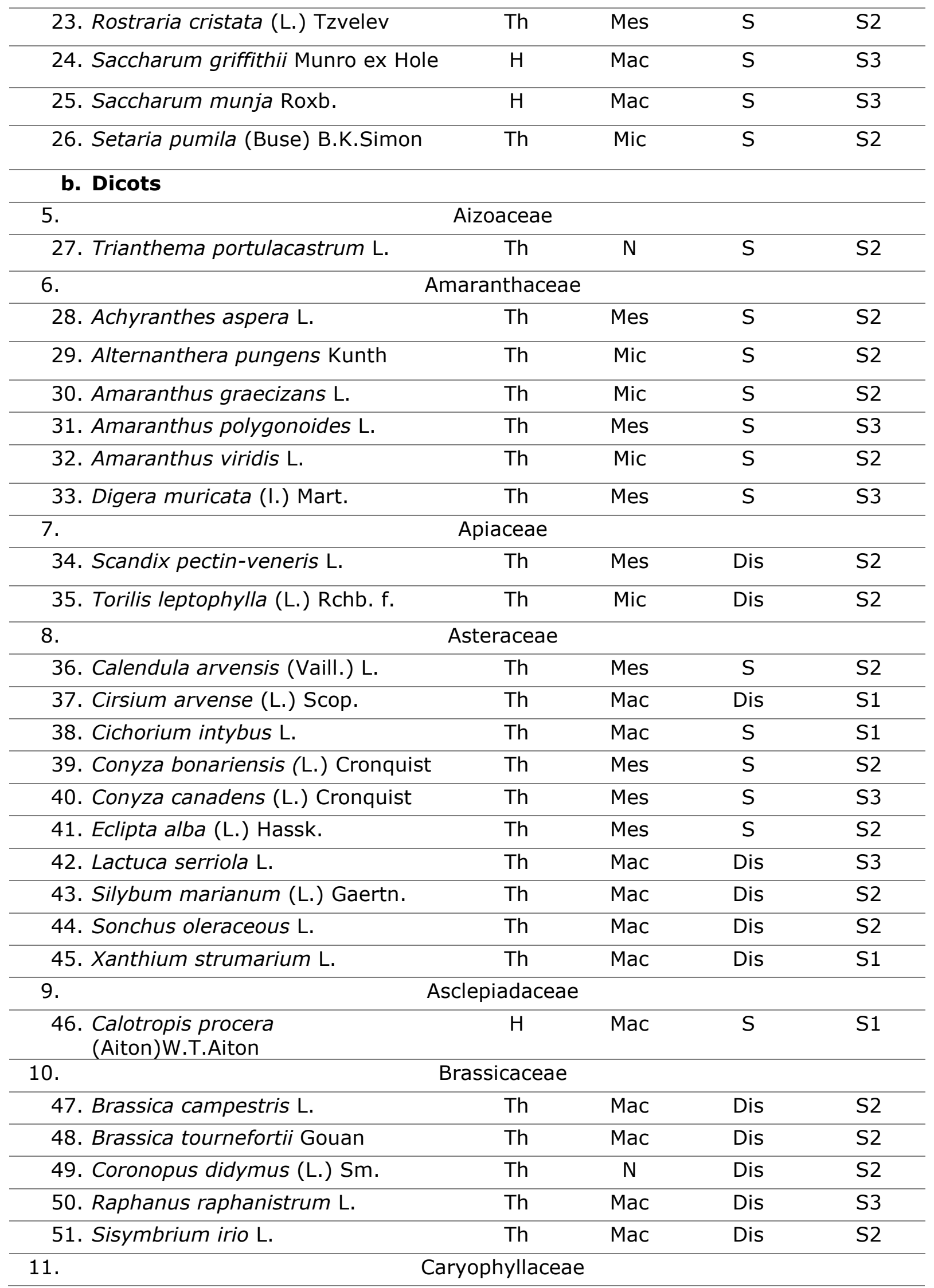


232 Abdullah, Syed Mukarram Shah et. al. Phytodiversity and Ecological ...

\begin{tabular}{|c|c|c|c|c|}
\hline 52. Cerastium glomeratum Thuill. & Th & Mes & $\mathrm{S}$ & $\mathrm{S} 2$ \\
\hline 53. Stellaria media (L.) Cirillo & Th & $\mathrm{N}$ & $\mathrm{S}$ & $\mathrm{S} 2$ \\
\hline 12. & \multicolumn{4}{|c|}{ Chenopodiaceae } \\
\hline 54. Chenopodium album L. & Th & $\mathrm{N}$ & $\mathrm{S}$ & S1 \\
\hline 55. Chenopodium ambrosioides L. & Th & Mac & Dis & S2 \\
\hline 56. Chenopodium murale L. & Th & Mes & Dis & S2 \\
\hline 13. Cleomaceae & & & & \\
\hline 57. Cleome viscosa L. & Th & Mes & Dis & S2 \\
\hline \multicolumn{5}{|l|}{ 14. Cucurbitaceae } \\
\hline 58. Citrullus colocynths (L.) Schrad. & Th & Mes & Dis & $\mathrm{S} 2$ \\
\hline \multicolumn{5}{|l|}{ 15. Convolvolaceae } \\
\hline 59. Convolvulus arvensis L. & Th & Mes & Dis & S1 \\
\hline 60. Ipomoea eriocarpa R.Br. & Th & Mic & Dis & S2 \\
\hline 61. Ipomoea hederacea Jacq. & Th & Mes & Dis & S3 \\
\hline \multicolumn{5}{|l|}{ 16. Euphorbiaceae } \\
\hline 62. Euphorbia helioscopia L. & Th & $\mathrm{N}$ & S & S2 \\
\hline 63. Euphorbia hirta L. & Th & Mic & S & $\mathrm{S} 2$ \\
\hline 64. Euphorbia hypericifolia L. & Th & Mes & S & $\mathrm{S} 2$ \\
\hline 65. Euporbia prostata Aiton & Th & $\mathrm{L}$ & S & S2 \\
\hline \multicolumn{5}{|l|}{ 17. Fumariaceae } \\
\hline 66. Fumaria indica (Hausskn.)Pugsley & Th & Mes & Dis & S2 \\
\hline \multicolumn{5}{|l|}{ 18. Lamiaceae } \\
\hline 67. Lamium amplexicaule L. & Th & Mic & Dis & S2 \\
\hline \multicolumn{5}{|l|}{ 19. Malvaceae } \\
\hline 68. Corchorus acutangulus L. & Th & Mes & S & S2 \\
\hline $\begin{array}{l}\text { 69. Malvastrum coromandelianum (L.) } \\
\text { Garcke }\end{array}$ & Th & $\mathrm{N}$ & S & S2 \\
\hline \multicolumn{5}{|l|}{ 20. Nyctiginaceae } \\
\hline $\begin{array}{l}\text { 70. Boerhavia procumbens Banks ex } \\
\text { Roxb. }\end{array}$ & Th & Mic & S & $\mathrm{S} 2$ \\
\hline \multicolumn{5}{|l|}{ 21. Oxalidaceae } \\
\hline 71. Oxalis corniculata L. & Th & L & Dis & S2 \\
\hline \multicolumn{5}{|l|}{ 22. Papilionaceae } \\
\hline 72. Lathyrus aphaca L. & Th & $\mathrm{N}$ & $\mathrm{S}$ & $\mathrm{S} 2$ \\
\hline 73. Medicago polymorpha L. & G & $\mathrm{L}$ & $\mathrm{S}$ & $\mathrm{S} 2$ \\
\hline 74. Melilotus officinalis (L.) Lam. & Th & $\mathrm{N}$ & $\mathrm{S}$ & $\mathrm{S} 1$ \\
\hline 75. Sesbania sesban (L.) Merr. & Th & $\mathrm{N}$ & $\mathrm{S}$ & $\mathrm{S} 2$ \\
\hline 76. Trifolium resupinatum L. & G & Mic & $\mathrm{S}$ & S1 \\
\hline 77. Vicia sativa Guss. & Th & $\mathrm{N}$ & $\mathrm{S}$ & S2 \\
\hline
\end{tabular}




\section{Phyllanthaceae}

78. Phyllanthus niruri L.

Th

N

S

$\mathrm{S} 2$

24. Plantaginaceae

79. Plantago lanceolata L.

Th

Mac

S

S2

80. Veronica persica Poir.

Th

N

Dis

S2

\section{Polygonaceae}

81. Emex spinosa (L.) Campd.

82. Persicaria maculosa Gray

Th Mic

Mic

Th Mes

$\mathrm{S} \quad \mathrm{S} 2$

83. Polygonum aviculare L.

Th L

84. Polygonum hydropiper L.

Th

85. Rumex dentatus L.

G

Mes

$\mathrm{S}$

$\mathrm{S} 2$

26. Primulaceae

86. Anagallis arvensis L.

Th

N

S

$\mathrm{S} 2$

27. Ranunculaceae

87. Ranunculus muricatus $\mathrm{L}$.

Th

Mes

Dis

$\mathrm{S} 2$

\section{Rubiaceae}

88. Galium aparine L.

Th

$\mathrm{N}$

S

S2

\section{Solanaceae}

89. Datura innoxia Mill.

Th Mac

S

S1

90. Physalis minima L.

Th

Mes

$\mathrm{S}$

$\mathrm{S} 2$

91. Solanum nigrum L.

Th

Mes

$\mathrm{S}$

S3

92. Withania somnifera (L.)Dunal

$\mathrm{H} \quad$ Mes

$\mathrm{S}$

S2

30. Verbenaceae

93. Verbena officinalis $L$.

Th

Mic

Dis

S2

94. Phyla nodiflora (L.) Greene

Th

N

$\mathrm{S}$

S2

31. Zygophyllaceae

95. Tribulus terrestris L.

Th

L

S

S3

Keys; The: therophytes, G: geophytes, H: hemicryptophytes, N: nanophylls, L: leptophylls, Ap: aphyllous, Mic: microphylls, Mes: mesophylls, Mac: macrophylls, S: simple, Dis: dissected, S1: pre-reproductive, S2: reproductive, S3: post-reproductive

Table 2. Summary of ecological characteristics of weeds of Sufaid Sung, Peshawar

\section{Parameters}

Life Forms

\section{Classes}

Therophytes

Hemicryptophytes

Geophytes No of species \%age

76

11

80

11.58

8

8.42

Total $=95$ 


\begin{tabular}{|c|c|c|c|}
\hline \multirow{7}{*}{ Leaf Sizes } & Mesophylls & 38 & 40 \\
\hline & Macrophylls & 18 & 18.95 \\
\hline & Microphylls & 18 & 18.95 \\
\hline & Nanophylls & 15 & 15.79 \\
\hline & Leptophylls & 5 & 5.26 \\
\hline & Aphyllous & 1 & 1.05 \\
\hline & \multicolumn{3}{|c|}{ Total $=95$} \\
\hline \multirow{4}{*}{ Leaf Shapes } & Simple & 68 & 72.34 \\
\hline & Dissected & 26 & 27.66 \\
\hline & Aphyllous & 1 & 1.05 \\
\hline & \multicolumn{3}{|c|}{ Total $=95$} \\
\hline \multirow{3}{*}{ Phenological stages } & Pre-reproductive & 12 & 12.63 \\
\hline & Reproductive & 69 & 72.63 \\
\hline & Post-reproductive & 14 & 14.74 \\
\hline
\end{tabular}

Table 3. Number of genera and species within the major groups of plants Major groups

No. of genera

Pteridophytes

Monocots

Dicots

22

60
No. of species

2

24

69
Species \%age

2.11

25.26

72.63

Table 4. Showing number of species of each family and their percentage

\begin{tabular}{rlcc}
\hline SNo. & Family & $\begin{array}{c}\text { No. } \\
\text { species }\end{array}$ & of \\
Percentage \\
\hline 1. & Poaceae & 22 & 23.16 \\
\hline 2. & Asteraceae & 10 & 10.5 \\
\hline 3. & Amaranthaceae & 6 & 6.3 \\
\hline 4. & Papilionacee & 6 & 6.3 \\
\hline 5. & Brassicaceae & 5 & 5.3 \\
\hline 6. & Polygonaceae & 5 & 5.3 \\
\hline 7. & Euphorbiaceae & 4 & 4.2 \\
\hline 8. & Solanaceae & 4 & 4.2 \\
\hline 9. & Chenopodiaceae & 3 & 3.2 \\
\hline 10. & Convolvolaceae & 3 & 3.2 \\
\hline 11. & Cyperaceae & 2 & 2.1 \\
\hline 12. & Apiaceae & 2 & 2.1 \\
\hline 13. & Caryophyllaceae & 2 & 2.1 \\
\hline 14. & Malvaceae & 2 & 2.1 \\
\hline 15. & Verbenaceae & 2 & 2.1 \\
\hline 16. & Equisetaceae & 1 & 1.05 \\
\hline 17. & Pteridaceae & 1 & 1.05 \\
\hline 18. & Aizoaceae & 1 & 1.05 \\
\hline
\end{tabular}




\begin{tabular}{llll}
19. & Asclepiadaceae & 1 & 1.05 \\
\hline 20. & Cleomaceae & 1 & 1.05 \\
\hline 21. & Cucurbitaceae & 1 & 1.05 \\
\hline 22. & Fumariaceae & 1 & 1.05 \\
\hline 23. & Lamiaceae & 1 & 1.05 \\
\hline 24. & Nyctiginaceae & 1 & 1.05 \\
\hline 25. & Oxalidaceae & 1 & 1.05 \\
\hline 26. & Phyllanthaceae & 1 & 1.05 \\
\hline 27. & Plantaginacea & 1 & 1.05 \\
\hline 28. & Primulaceae & 1 & 1.05 \\
\hline 29. & Ranunculaceae & 1 & 1.05 \\
\hline 30. & Rubiaceae & 1 & 1.05 \\
\hline 31. & Zygophyllaceae & 1 & 1.05 \\
\hline
\end{tabular}

\section{CONCLUSION}

The data shows a considerable amount of diversity in weeds distribution. However, diversity in cultivated areas is much lower than in uncultivated areas. This is possibly due to anthropogenic activities and use of different weeds control measures. Despite of their impact on crops and vegetable yield, weeds have medicinal and therapeutic uses. We recommend that these weeds can be used for their medicinal and therapeutic purposes. To achieve this goal, further ecological and ethnobotanical assessments are required. The present study will provide a reference and helping tool in such circumstances. 


\section{REFERENCES CITED}

Ali, S., Shah, S. Z., Ali, K., Khan, M. S., Ullah, S., Khan, W. M. \& Sajjad, M. A. 2015. Diversity of Weeds and Their Ecological Characteristics At Tehsil Manki Sharif, District Nowshera, Pakistan. Pak. J. Weed Sci. Res., 21.

Anwar, M., Akhtar, N., Khalid, S. \& Zeb, H. 2020. Eco-floristic study of weed flora of maize crop in District Swabi, Khyber Pakhtunkhwa, Pakistan. Pak. J. Weed Sci. Res, 26, 499-506.

Badshah, L., Hussain, F. \& Sher, Z. 2016. Floristic inventory, ecological characteristics and biological spectrum of plants of Parachinar, Kurram Agency, Pakistan. Pak. J. Bot, 48, 1547-1558.

Basit, A., Khan, S., Sulaiman Shah, S. \& Shah, A. A. 2019. Morphological features of various selected tree species on the greater university campus Peshawar, Pak. Int J. Bot. Studies, 4, 92-97.

Gurmani, A. R., Khan, S. U., Mehmood, T., Ahmed, W. \& Rafique, M. 2020. Exploring the allelopathic potential of plant extracts for weed suppression and productivity in wheat ( $T$. aestivum L.). Gesunde Pflanzen, 19.

Haq, S. M., Malik, A. H., Khuroo, A. A. \& Rashid, I. 2019. Floristic composition and biological spectrum of keran-a remote valley of Northwestern Himalaya. Acta Ecologica Sinica, 39, 372-379.

Hussain, F. 1989. Field and laboratory manual of plant ecology, National Academy of Higher Education, University Grants Commission.

Hussain, F., Shah, S. M., Badshah, L. \& Durrani, M. J. 2015. Diversity and ecological characteristics of flora of mastuj valley, district Chitral, Hindukush Range, Pakistan. Pak. J. Bot, 47, 495-510.

Ibrahim, M., Khan, M., Ali, S., Razzaq, A., Zaman, A., Iqbal, M. \& Jan, F. 2019. Floristic composition and species diversity of plant resources of rural area "Takht Bhai" District Mardan, $\mathrm{KP}$, Pakistan. Medicinal \& Aromatic Plants (Los Angeles), 8, 21670412.19.

Iqbal, M., Khan, S. M., Khan, M. A., Ahmad, Z., Abbas, Z., Khan, S. M. \& Khan, M. S. 2017. Distribution pattern and species richness of natural weeds of wheat in varying habitat conditions of district malakand, Pakistan. Pak. J. Bot, 49, 2371-2382.

Khan, A. \& Ali, M. 2019. Impact of built environment on groundwater depletion in Peshawar, Pak. J. of Himalayan Earth Sciences, 52, 86.

Khan, H., Marwat, K. B., Hassan, G. \& Khan, M. A. 2013a. Socio-economic impacts of parthenium (Parthenium HysterophorusL.) In Peshawar Valley, Pakistan.Pak. J. Weed Sci. Res. 19(3): 275-293.

Khan, I., Jan, A. U., Gul, F., Ali, K., Ghaffar, A., Ahmed, S. \& Ahmad, N. 2011. Weeds As A major constraint in wheat production in district Peshawar. Pakistan Journal Of Weed Science Research, 17.

Khan, I., Javed, T., Khan, A., Lei, H., Muhammad, I., Ali, I. \& Huo, X. 2019. Impact assessment of land use change on surface temperature and agricultural productivity in Peshawar-Pakistan. Environmental Science and Pollution Res., 26, 33076-33085.

Khan, M., Hussain, F. \& Musharaf, S. 2013b. Floristic composition and biological characteristics of the vegetation of Sheikh Maltoon Town District Mardan, Pakistan. Annual Research \& Review In Biology, 3141.

Khan, M. N., Hadi, F., Razaq, A. \& Shah, S. M. 2017. Utilitarian aspects of weeds and their ecological characteristics in Ochawala Valley, District Charsadda, Pakistan. Aprn J Agric and Biol. Sci. 12, 5, 182-189. 
Naila, S., Rehman, A. U. \& Shah, S. M. 2017. Ecology of weeds of garlic crop at botanical garden, University of Peshawar, Pakistan. Pak. J. Weed Sci. Res. 23.

Naveed, S., Khattak, I. \& Marwat, K. B. 2019. Ethnomedicinal study of weeds in maize rice and tobacco fields of tehsil Razzar District Swabi Pakistan. Pak. J. Weed Sci. Res., 25.

Saeed, M., Chaudhry, K., Ashraf, I., Usman, M., Ejaz, R., Shoaib, M. \& Riaz, I. 2020. Impact of public extension services for effective weed management practices in wheatmaize cropping pattern in Faisalabad Punjab, Pakistan. Biological and Clinical Sci. Res. J., 2020, E032E032.

Shah, S. R. U., Muhammad, Q., Khan, I. A. \& Shah, S. A. U. 2006. Study of medicinal plants among weeds of wheat and maize in Peshawar Region. Pak. J. of Weed Sci. Res., 12, 191-197.
Uddin, A., Begum, M., Uddin, M., Akter, F. \& Islam, K. 2018. Floristic composition of weeds in T. Amanpotato-boro rice cropping pattern in Bangladesh. J. Res. In Weed Science, 1, 48-62.

Usman, K., Rehman, H. U., Khudadad, S., Pervaiz, K., Khan, M. W., Ali, S. Z. U. A., Maqsood, M. J., Jawad, S. M. \& Ahmad, A. 2017. Assessment of heavy metals in river Kabul at Warsak Peshawar Khyber Pakhtunkhwa, Pakistan.

Zeb, U., Ali, S., Li, Z. H., Khan, H., Shahzad, K., Shuaib, M. \& Ihsan, M. 2017. Floristic diversity and ecological characteristics of weeds at Atto Khel Mohmand Agency, KPK, Pakistan. Acta Ecologica Sinica, 37, 363-367. 